\title{
Az IKT-eszközök használata az idegennyelv-oktatásban hátrányos helyzetủ tanulók iskoláiban
}

Az információs és kommunikációs technológiai eszközök (a továbbiakban IKT) oktatásban betöltött szerepének célja az oktatás megkönnyítése és a hatékony tanulás megvalósítása. Az IKT-eszközök és -módszertan kiválóan alkalmazható a nyelvtanítás, -tanulás folyamatában is (Matthey 2006; Czékmán 2018). Jelen kutatás 2014 tavaszán a Klebelsberg Intézményfenntartó Központ Nyíradonyi Tankerületének öt intézményében készült kérdőíves módszerrel 7-8. osztályos tanulók körében ( $\mathrm{N}=230$ fő) (a Nyíradonyi Tankerület a 134/2016-os kormányrendelet értelmében a Debreceni Tankerülethez került). A kutatás során a hátrányos helyzetű tanulók idegen nyelvi órákon használt IKT-eszközök iránti attitűdjét vizsgáltuk. Arra kerestük a választ, hogyan jelentek meg az IKT-eszközök ezeken az órákon, és hogyan reagáltak erre a tanulók. Azt feltételeztük, hogy a magas szintü tanórai IKT-használat pozitívan befolyásolja az idegennyelv-tanulás iránti tanulói motivációt. Az eredményeink azt mutatják, hogy a tanulók az IKT-eszközök idegen nyelvi órákon történő használatának fontosságát, az eszközökben való jártasságukat és azok pozitív hatását és motiváló erejét hangsúlyozták.

Kulcsszavak: közoktatás, hátrányos helyzetüt tanulók, idegennyelv-oktatás, IKT-eszközök, társadalmi egyenlőtlenség

\section{A szerző(k)ről}

Barnucz Nóra a Nemzeti Közszolgálati Egyetemen egyetemi tanársegéd

Fónai Mihály a Debreceni Egyetem Állam- és Jogtudományi Karán szociológus professzor

Így hivatkozzon erre a cikkre:

Barnucz Nóra, Fónai Mihály „Az IKT-eszközök használata az idegennyelv-oktatásban hátrányos helyzetű tanulók iskoláiban”, Információs Társadalom, XX. évf. (2020) 1. szám, 7-28.

$\Longrightarrow \quad$ https://dx.doi.org/10.22503/inftars.XX.2020.1.1 $=$

A folyóiratban közölt müvek

a Creative Commons Nevezd meg! - Ne add el! - Így add tovább! 4.0

Nemzetközi Licenc feltételeinek megfelelöen használhatók. 


\section{The Use of ICT in Language Education in Schools of Disadvantaged Students}

The aim of the information and communication technology devices (from now on: ICT) in education would be the accomplishment of making teaching easier and learning effectively in the classroom. The ICT tools and methodology can be applied perfectly to the process of language teaching and learning (Matthey 2006, Czékmán 2018). Quantitative research was carried out in spring 2014 in five primary schools of the Klebersberg Institution Maintenance Centre of Nyíradony School District Centre (it was involved in Debrecen School District Centre in the act of 134/2016 agreement). The students in 7-8 years were responded $(\mathrm{N}=230)$ to the questionnaire where the attitude of disadvantaged students was analyzed related to the use of ICT in the English language learning. We tried to explore how ICT tools are involved in language education and how the students react to this phenomenon. Based on our hypothesis, we state that the use of ICT in language teaching in a higher level has a more positive effect on students' motivation related to language learning. The results show that the students emphasize the importance and positive effect of ICT in education, and their expertise was also highlighted

Keywords: public education, disadvantaged students, language education, ICT devices, social inequalities 


\section{Bevezetés}

Napjainkban rendkívül fontos az idegen nyelvek ismerete. Magabiztos használatuk elengedhetetlen a stabil munaerő-piaci helytálláshoz (Einhorn 2015; Molnár és Uricska 2018). Azonban az idegen nyelven történő kommunikáció számos esetben problémás, aminek igaz, a gyökerei elsősorban a pedagógusok IKT-módszertanban való alacsony színvonalában keresendők, jelen tanulmányban mi mégis a másik oldalra, a tanulókra koncentrálunk.

A tanulmány relevanciáját az idegen nyelvi kommunikációs kompetencia tanulói körben tapasztalt hiányosságai adják. Több mint két évtizeddel a rendszerváltás után a magyarok idegennyelv-tudása még mindig alulmaradt más országok (például Olaszország, Spanyolország, Egyesült Királyság stb.) eredményeihez képest (Europeans and their Languages 2012, 15). Tény, hogy az oktatásban szemléletváltásra van szükség - nemcsak a digitális világ változásai miatt, hanem az idegennyelv-oktatás vonatkozásában is - ahhoz, hogy a tanulóink eredményesebbek és sikeresebbek lehessenek. Ezt indokolják a társadalmi szinten bekövetkezett változások is, mint például a digitális eszközhasználat, munkaerő-piaci igények, az elvárt probléma-megoldási technikák stb., amelyek elsajátítása indokolt és szükséges ahhoz, hogy tanulóink stabilan tudják megállni helyüket az oktatásban és a munkaerőpiacon egyaránt (Einhorn 2015).

\section{A kutatás relevanciája}

Az oktatás helyzetét tovább nehezítették azok a demográfiai és társadalmi szintű problémák, amelyek miatt rohamosan megnövekedett a hátrányos helyzetü tanulók aránya az oktatásban (Einhorn 2015). A változtatást igénylő trendek mellett az alulmotivált, rosszul szocializált és mélyszegénységben élő tanulók arányának növekedése is nagy problémákat okozott. Egy német kutatás (Bericht über die Durchführung des Aktionsplans... 2007) eredményei alapján megállapítható, hogy a nyelvtanításban is nagy társadalmi egyenlőtlenségek mutatkoznak, hiszen azok a tanulók, akik alacsonyabb státusú háttérrel rendelkeznek, jobban rászorulnának a közoktatásban ingyenesen hozzáférhető nyelvoktatásra, mégis kevesebb lehetőséget kapnak az iskolában, mint azok, akik jobb szociális háttérrel rendelkeznek (Bericht über die Durchführung des Aktionsplans...2007). Az említett szociokulturális hátrányból érkező diákok iskolai teljesítménye rendre alulmarad azon diákok iskolai teljesítményétől, akik átlagos vagy annál is jobb családi körülmények közül érkeznek az iskolapadba. Ezt a jelenséget már korábban is vizsgálták (Erdészné és Timár 196;, Gazsó 1976; Ferge 1972; Molnár 1996), de Pusztai (2004) is hasonló megállapításokat tett, amikor a felekezeti középiskolások tanulmányi és tanulmányokon kívüli teljesítményükkel foglalkozott. A gyengébb iskolai teljesítménnyel rendelkező diákok képességének fejlesztése és a jobb képes- 
ségekkel rendelkező diákok tehetséggondozása sem történhet meg eredményesen az iskola fejlesztése nélkül. Ez Bernstein (1975) nyelvi szocializációs elméletével is magyarázható, miszerint ha a gyermek érzékeny az iskolai kommunikációs rendszerére, akkor az pozitív hatással lesz a társadalmi fejlődésére, iskolai teljesítményére; ha viszont a gyermek nem érzékeny az iskola kommunikációs rendszerére, akkor egyfajta kulturális szakadék alakulhat ki a közössége és az iskola között. A probléma tárgya a társadalmi szelekcióban rejlik. Ez abban mutatkozik meg, hogy a társadalmilag leginkább értékesnek tartott iskolatípusok tanulói között a magasabb társadalmi státusú szülők gyermekei felül-, míg az alacsonyabb társadalmi státusszal rendelkező szülők gyermekei alulreprezentáltak. Ez fordítva is megfigyelhető. A különböző iskolatípusokba való irányulás kiindulópontja az elért tanulmányi eredmény. Kutatási eredmények bizonyítják, hogy a jó tanulók között a jobb státusú szülők gyermekei, míg a gyengék, vagy a túlkoros tanulók között a rossz státusú szülők gyermekei felülreprezentáltak. Ennek oka abban rejlik, hogy az iskola a társadalmi különbségeket képességekben megnyilvánuló különbségekké transzformája (Meleg 1996). Denis (1974) szerint az iskola éppen annyira tekinthető felelősnek a korai lemorzsolódásért és a tanulók gyenge teljesítményéért, mint a tanulók otthoni környezete. A kutató azon az állásponton van, hogy a teljesítmények különbözőségét nemcsak, hogy elégtelen, de egyenesen tautologikus dolog pusztán a motivációval magyarázni (Denis 1974), hiszen a motiváció sok különböző tényező összességéből áll (McClelland 1958). Esetünkben úgy tekintünk a motivációra mint oktatással kapcsolatos szubkulturális tényező. Minél erősebb az osztályozás, annál tudatlanabbnak tekintik azt, akinek alacsony a státusa és kevés a joga (Bernstein 1974).

Mindezek ellenére a felsőoktatás szerepvállalása is nélkülözhetetlen a tanárképzés kapcsán, hiszen a pályakezdő pedagógusokat olyan szakmódszertani felkészítéssel kellene ellátni, amely rugalmasan illeszkedik és alkalmazkodik a 21. század szinte napról napra történő változásaihoz (Einhorn 2015; Buda 2017; Fehér, Czékmán és Aknai 2018). Felsőoktatás-kutatásokkal foglalkozó szakemberek írnak arról, hogy a hallgatók az elégedettségi felmérések során az idegen nyelvi oktatás minőségét megkérdőjelezik, különböző problémákra mutatnak rá, mint például: nagy csoportlétszámok, kevés óraszám, csökkenő színvonal, egységes nyelvi követelményrendszer hiánya, kevés kommunikációs lehetőség, a nyelvtanárok motiválatlansága, kreativitás hiánya (Szántó 2004; Novák és Morvai 2017). Az idegennyelv-tanárok célja, hogy hatékonyan és érthetően közvetítsék a célnyelvet a tanulók számára. Ma a modern nyelvoktatásban erre számtalan lehetőség adódhat az új digitális technológiák, IKT-eszközök segítségével. Ezekkel az eszközökkel éppúgy vonzóbbá tehető a nyelv tanítás, mint ahogy egyszerübb motiválni a tanulókat, akik aktív részesei lehetnek a tanóráknak. (Kétyi 2016).

Számos magyarországi kutatás foglalkozik a diákok nyelvtanulási motivációjával. Csizér és Dörnyei (2005) 8. osztályos magyar diákok motivációját vizsgálta klaszteranalízis segítségével, ahol 4 különálló motivációs csoportba 
sorolták a tanulókat, majd összevetették Dörnyei idegen nyelvi énrendszerének első két elemével. Az eredmények azt mutatták, hogy a sikeresebb tanulók esetén erős szükséges nyelvi énkép (azon tulajdonságok csoportja, melyeket elképzelése szerint elvárnak tőle, kevésbé internalizált tulajdonságok összessége) volt megfigyelhető.

Szocioökonómiai szemszögből közelítve meg a témát, Kormos és Csizér (2015) azt tapasztalták, hogy a család befolyásolja a nyelvtanulást és a motiváció fenntartásában is rendkívül fontos szerepe van. Kvalitatív kutatást végeztek, melynek keretein belül 40 interjút készítettek 8. osztályos angol és német nyelvet tanuló diákokkal. Az eredmények azt mutatták, hogy a jó nyelvtanulónak minősülő diákok 85\%-a kap segítséget otthonról. A nyelvtanulás a társadalom és kultúra részeként, kevésbé kutatott terület mind hazai, mind nemzetközi szinten. Butler (2013) is hiányolja a kutatásokból a szocioökonómiai tényezők vizsgálatát. Tanulmányában arra mutat rá, hogy a globalizáció következtében az angol nyelv szerepe felértékelődött, ámbár az angol nyelvtudásban hiányosságok tapasztalhatók. Azt feltételezi, hogy ennek okai a diákok szocioökonómiai státusának különbözőségében keresendők (Novák és Morvai 2017).

A felsorolt érvek mind azt támasztják alá, hogy módszertani megújulásra van szükség az idegennyelv-oktatása terén, amelyben az IKT-eszközök is hangsúlyos szerepet kaphatnak. Kutatásunk ennek alátámasztását igyekszik elősegíteni. Munkánk során angol nyelvet tanuló 7-8. évfolyamos tanulók IKT-eszközökkel gazdagított idegennyelv-tanulás iránti attitűdjét vizsgáljuk. A vizsgált iskolák tanulóinak az összetétele - részben a szegregált és szelektív magyar iskolarendszer, részben a vizsgált térség fejlettsége miatt - főleg alacsony szocioökonómiai háttérü, ami lényegesen befolyásolhatja az oktatási módszerek hatékonyságát és eredményességét. Mivel a tanulmány hátrányos helyzetű iskolák tanulóira irányul, így a megállapításaink elsősorban természetesen ezekre az intézményekre és diákjaikraérvényesek. Novák és Morvai (2017:55) tanulmányában hangsúlyozzák, hogy Max Weber (1982) és Bourdieu (1978) általánosabb érvényủ megállapításai a nyelvtanulásra is alkalmazhatók, miszerint a feltörekvő középréteg optimista jellemzői révén képes arra, hogy a rendelkezésre álló anyagi erőforrásokat a jövőbeni tervek megvalósításába fektesse (például a gyermekek jövőbeni terveinek pénzbeli vagy erkölcsi támogatása). Ezt kutatási eredményeik is alátámasztják, hiszen a magasabb iskolai végzettségű szülők esetében megfigyelhető, hogy gyermekeik nyelvtudását az iskolán kívüli képzésekkel is támogatják (anyagi ráfordítás).

\section{A hátrányos helyzet fogalmának értelmezései}

A hátrányos helyzet kifejezést számos tudományterület használja és definiálja. Értelmezését a vizsgálódás célja is befolyásolja (Liskó 2002). Gidáné (2006)röviden, tömören így fogalmazza meg a hátrányos helyzet definícióját: „a hátrányos helyzet vagy depriváció egyes embereknek vagy embercsopor- 
toknak olyan társadalmi helyzete, amelyben az erőforrások elérhetősége az átlagosnál jelentős mértékben korlátozottabb” (Gidáné 2006, 75). A fogalom nemzetközi értelmezései csak árnyalatnyi különbségeket mutatnak, de abban megegyeznek, hogy a hátrányos helyzet a család rosszabb szociális háttere és kedvezőtlen gazdasági jellemzői alapján állapítható meg (Edwards 1974; Heckman és Masterov 2007). Pedagógiai értelemben a hátrányos helyzetet gazdasági, társadalmi és kulturális jellemzők befolyásolják, amelyek az egyes tanulók iskolai teljesítménye, az előrehaladás szempontjából a többséghez képest kedvezőtlen helyzetet teremtenek (Fejes 2006; Fejes és Józsa 2007).

Az oktatásszociológiában a hátrányos helyzet definíciójának meghatározása szempontjából Kozma alapvető munkája (1975) játszott nagy szerepet. Szociológiai értelemben a marginális helyzet fogalom alatt azokat a társadalom perifériájára került csoportokat értjük, akik gazdasági, társadalmi vagy földrajzi szempontból kedvezőtlen helyzetbe kerültek (Balogh 2002). A fogalom jogi kategóriaként is értelmezhető. A köznevelési törvény a 2013/2014. tanévtől a gyermekek védelméről és a gyámügyi igazgatásról szóló 1997. évi XXXI. törvényt alkalmazza a hátrányos helyzetre vonatkozóan (Varga 2014). A hátrányos helyzet kialakulását számos tényező befolyásolja, melyek közül több megjelent már a hátrányos helyzetű települések főbb jellemzői között is.

A kutatás során az említett kutatók definíciói alapján a társadalmi, kulturális gazdasági és földrajzi szempontból is kedvezőtlen helyzetbe került csoportokat nevezzük hátrányos helyzetűnek. Mindegyik tényező mögött létezhetnek az egyéntől függő és független okok (alacsony szülői iskolai végzetség, munkanélküliség, a szülők válása stb.), melyek negatívan befolyásolják az egyén sorsát. Az említett tényezők és a mögöttük rejlő okok eredményeképpen a társadalom perifériájára került csoportokról beszélhetünk, ahol a tanulók iskolai teljesítménye lényegesen alulmarad a magasabb státusú tanulók iskolai teljesítménye mögött (Fejes 2006; Fejes és Józsa 2007).

\section{IKT az idegennyelv-oktatásban}

A sikeres kommunikációhoz elengedhetetlen a megfelelő mennyiségű szó ismerete, azonban évek óta kevesebb figyelmet kapott a szókincstanítás - szemben a nyelvtani ismeretek bővítésével - az idegen nyelvi órák keretében (Vecsernyés és Wichmann 2013). Folse (2004) véleménye szerint a szókincstanulás fontosabb, mint a nyelvtan tanulása (Folse 2004), mivel éppen a szókincsből eredően történnek a legsúlyosabb félreértések. „Rossz nyelvtannal is ki tudja magát fejezni az ember, de ez szavak nélkül lehetetlen” (Folse 2004, 1-10). Az oktatásban egyre nagyobb hangsúlyt fektetnek a kommunikáció fejlesztésére, azonban ehhez elengedhetetlen a széleskörű szókincs ismerete. Kutatási vizsgálatok bizonyítják, hogy a tanulók a prioritási listájukon is kiemelkedő helyen kezelik a szókincsfejlesztést. Bárdos (2000) szerint csupán arról van szó, hogy a szókincstanítás metodikája nem fejlődött megfelelőképpen és a szakirodalom- 
ban ez úgy csapódik le, mintha a szókincstanítás egy elhanyagolt terület lenne. Számos nyelvtanító módszer létezik, amellyel bővíthető a tanuló szókincse (Bárdos 2000, 77-78). Nissila (2011) finn kutató szerint nem elegendő az, ha a tanulók az órán ismerkednek a kifejezésekkel, hanem annak rögzítésére is időt kell szánni, és energiát kell befektetni az önálló szótanulásra is. Ahhoz, hogy jól bevéssük az egyes szavakat, jó memóriára is szükség van. Nissila (2011) problémaként veti fel, hogy ma is gyakran előfordul, hogy a tanulók a nyelvórákon különálló szavakat, szólistákat kapnak, amelyeket másnapra memorizálniuk kell anélkül, hogy bármiféle mélyebb ismereteik lennének az adott lexikai egységekről. Crystal (1998) azon a véleményen van, hogy az anyanyelv sajátosságai akár pozitívan, akár negatívan is tükröződhetnek a második nyelv elsajátítása során azáltal, hogy az anyanyelvből hangok, szerkezetek vihetők át az új nyelvre. A két nyelv közötti hasonlóságok pozitív átvitelt, míg a különbözőségek negatív átvitelt eredményezhetnek, melyek hibákat okozhatnak a második nyelv elsajátítása során. Egyre inkább a tanulók anyanyelvi szókincsének hanyatlása tapasztalható, valamint idegen nyelvi szókincsbázisuk is alacsony, amit a tanuló szociokulturális háttere is befolyásol. Tény, hogy a nyelvtanulás egyik kiemelkedő területe a szókincsfejlesztés, ami nélkülözhetetlen a kommunikációs és a nyelvtani ismeretek fejlesztéséhez (Ürmösné 2017; Barnucz 2019b, 2019c), azonban ehhez megfelelő eszközre és stratégiára is szükség van. A National Reading Panel (2000) jelentésében listába szedte azt az öt alap szókincstanulási megközelítést, amelyek együttes használata javasolt lenne: egyértelmű utasítás (explicit instruction), közvetett utasítás (indirect instruction) multimédiás módszerek (multimedia methods), befogadóképességet elősegítő módszerek (capacity methods) és asszociációs módszerek (association methods). Ezekhez a módszerekhez rendkívül jól igazodik az 50-es, 60-as években jellemző behaviourista elképzelés, miszerint a nyelvtanulás utánzáson és megerősítésen alapszik, amely röviden annyit jelent, hogy a nyelvtanuló hallja az idegen nyelvü szót, kifejezést, utánozza azt, és többszöri ismétléssel, gyakorlással szert tesz az új szókincsre, vagy netán szókészletre (Polonyi, Abari és Nótin 2009; Borszéki 2013, 2014a). A kognitív pszichológia elmélete alapján a nyelvtanulók kreativitásukat alkalmazva (kognitív képesség egyike), önállóan alakíthatnak ki szabályokat az idegen nyelv tanulása során, alkalmazzák azokat, majd módosítanak azokon, ha szükségét látják. Azonban ez a megközelítés számos hibaforrásnak adhat teret (Polonyi, Abari és Nótin 2009). Selinker (1972) véleménye szerint a nyelvtanulók a nyelvtanulás során egy köztes nyelv birtokában vannak, mely nem azonos sem az anyanyelvvel, sem az adott második nyelvvel. Egyre több modell a szociális környezet feltérképezésével közelít a témához. Például Tomasello (2003) is a strukturált szociális környezet (amelybe a gyerek beleszületik), valamint a tanuló szociális kognitív kapacitása tényezők felől közelít a témához.

A mai nyelvtanulók - a 21. század hatalmas lehetőségeinek köszönhetően - főleg az első elméleti modellt alkalmazhatják kreatívan, hiszen ha akarják, hallgathatják, utánozhatják, ismételhetik, gyakorolhatják az egyes kifejezéseket, ezáltal feltételezhetően rögzítve is az adott szókészletet (Matthey 2006). 
Kevésbé adhatunk teret a tanulók önálló és kreatív szabályalkotó hipotézisnek, hiszen ezáltal csak növelnék az elsajátítás folyamatát (a nyelvtani szabályok pontos alkalmazása). Ami a harmadik Tomasello-féle (2003) szociális aspektusból közelítő elméletet illeti, egy olyan modellről van szó, amely valójában nélkülözhetetlen, tekintettel arra, hogy egy tanuló tanulási képességeit, motivációját, kreativitását a szociális környezet lényegesen befolyásolhatja, és ettől a szociális környezettől függetlenül kell kibontanunk a tanuló szociális kognitív kapacitását (Barnucz 2019a) A következő fejezetben a kutatás módszertani lépéseit mutatjuk be, amelyek segítségével sikerült feltérképeznünk bizonyos ingerszegény településeken élő diákok nyelvtanulási, valamint IKT-attitűdjét.

\section{A kutatás háttere}

A kutatás Hajdú-Bihar megye hátrányos helyzetű településein zajlott. A következő táblázat szemlélteti a hátrányos helyzetű tanulók arányát fenntartók szerinti bontásban (1. táblázat). Azt láthatjuk, hogy a megyében 2007-2016 között a hátrányos helyzetű tanulók aránya lényegesen magasabb volt az állami fenntartású iskolákban az országos átlaghoz, sőt az egyházi fenntartású iskolákhoz képest is. Azonban érdemes megfigyelni azt is, hogy az egyházi fenntartású iskolákban tanuló hátrányos helyzetű diákok százalékos aránya is magasabb az országos átlaghoz képest.

\begin{tabular}{|c|c|c|c|c|c|c|c|c|c|c|c|c|c|c|}
\hline & \multicolumn{2}{|c|}{2007} & \multicolumn{2}{c|}{2010} & \multicolumn{2}{c|}{2012} & \multicolumn{2}{|c|}{2013} & \multicolumn{2}{|c|}{2014} & \multicolumn{2}{|c|}{2015} & \multicolumn{2}{|c|}{2016} \\
\hline (\%) & $\mathrm{A}$ & $\mathrm{E}$ & $\mathrm{A}$ & $\mathrm{E}$ & $\mathrm{A}$ & $\mathrm{E}$ & $\mathrm{A}$ & $\mathrm{E}$ & $\mathrm{A}$ & $\mathrm{E}$ & $\mathrm{A}$ & $\mathrm{E}$ & $\mathrm{A}$ & $\mathrm{E}$ \\
\hline $\begin{array}{c}\text { Országos } \\
\text { átlag }\end{array}$ & 29,3 & 15,3 & 37,0 & 25,0 & 35,4 & 31,6 & 30,2 & 26,6 & $\mathbf{1 7 , 6}$ & $\mathbf{1 5 , 4}$ & 7,1 & 7,0 & 7,1 & 6,7 \\
\hline $\begin{array}{c}\text { Hajdú- } \\
\text { Bihar me- } \\
\text { gye }\end{array}$ & 40,6 & 9,8 & 50,9 & 27,2 & 49,8 & 38,2 & 47,3 & 39,5 & $\mathbf{2 5 , 7}$ & $\mathbf{1 9 , 4}$ & 10,8 & 12,0 & 10,3 & 11,3 \\
\hline
\end{tabular}

1. táblázat: Hátrányos helyzetű tanulók aránya fenntartók szerinti bontásban (\%) (saját szerkesztés)

Forrás: http://edumap.ofi.hu/ (Á=állami iskolákban, E=egyházi iskolákban)

A kutatásunk során nem volt lehetőségünk a tanulók szocioökonómiai hátterének vizsgálatára. Ennek legfőbb oka, hogy a kérdőívünk erre vonatkozó kérdéseit a fenntartó nem támogatta. Így az oktatási hivatal online statisztikai adatokat lekérő programjának köszönhetően (edumap) tudjuk azt, hogy a vizsgált alapfokú oktatási intézmények tanulóinak nagy része hátrányos helyzetű (2. táblázat). A vizsgált intézményeink korábban a Nyíradonyi Járási Hivatal Illetékességi területeihez tartoznak: Álmosd, Bagamér, Fülöp, Nyíracsád, Nyírábrány, Nyírmártonfalva, Nyíradony, Újléta, Vámospércs. Az adatok jól mutatják, 
hogy a Hajdú-Bihar megyéhez tartozó Nyíradonyi Járási Hivatal illetékességi területén nappali rendszerü, állami fenntartású általános iskolákban tanuló hátrányos helyzetű diákok számának százalékos aránya a vizsgált időszakban (2014) jelentősen magasabb az országos átlaghoz képest (Fónai et al. 2014). A térkép pedig Hajdú-Bihar megye Járási Hivatalainak illetékességi területéhez tartozó nappali rendszerü, állami fenntartású általános iskolában tanuló hátrányos helyzetű diákok számának százalékos arányát mutatja (1. ábra).

\begin{tabular}{|c|c|c|c|c|c|c|c|}
\hline Terület & $\mathbf{2 0 0 7}$ & $\mathbf{2 0 1 0}$ & $\mathbf{2 0 1 2}$ & $\mathbf{2 0 1 3}$ & $\mathbf{2 0 1 4}$ & $\mathbf{2 0 1 5}$ & $\mathbf{2 0 1 6}$ \\
\hline $\begin{array}{c}\text { Országos } \\
\text { átlag }\end{array}$ & $29,29 \%$ & $36,94 \%$ & $35,38 \%$ & $30,20 \%$ & $\mathbf{1 7 , 5 7 \%}$ & $\mathbf{7 , 1 2} \%$ & $7,08 \%$ \\
\hline $\begin{array}{c}\text { Nyírado- } \\
\text { nyi járás }\end{array}$ & $58,88 \%$ & $75,54 \%$ & $77,34 \%$ & $76,64 \%$ & $\mathbf{4 9 , 1 7 \%}$ & $\mathbf{2 2 , 2 8 \%}$ & $21,30 \%$ \\
\hline
\end{tabular}

2. táblázat: Hátrányos helyzetű tanulók számának százalékos aránya Hajdú-Bihar megyéhez tartozó Nyíradonyi Járási Hivatal Illetékességi területeinek nappali rendszerü, állami fenntartású általános iskoláiban (saját szerkesztés)

Forrás: http://edumap.ofi.hu/
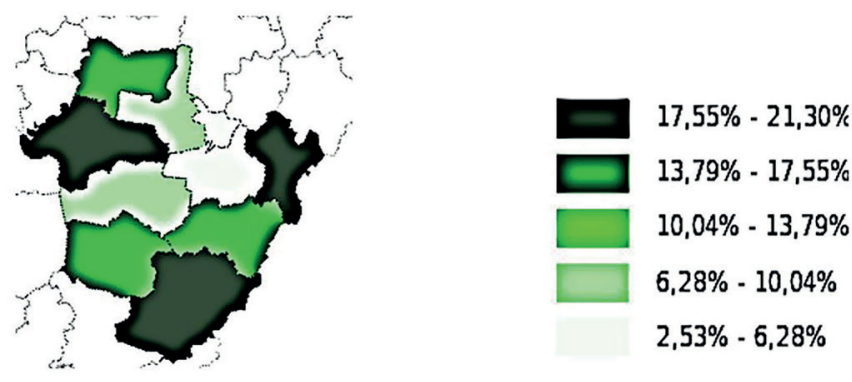

1. ábra: Hajdú-Bihar megye Járási Hivatalainak Illetékességi területeihez tartozó nappali rendszerü, állami fenntartású általános iskolában tanuló hátrányos helyzetű diákok számának százalékos aránya

Forrás: http://edumap.ofi.hu/

A felekezeti iskolákban tanuló hátrányos helyzetű diákok számának növekedését Pusztai (2014) is alátámasztja eredményeivel, azt mutatják, hogy a felekezeti iskolákban tanuló hátrányos helyzetű tanulók aránya is évről évre növekedni látszik, azonban az állami fenntartású intézmények hátrányos helyzetű tanulóinak százalékos arányához képest még mindig kevesebb

1 A százalékos mutatók 2014-es, lényeges változását a jogi szabályozás változása, a hátrányos és a halmozottan hátrányos helyzet szabályozásának a változása magyarázza (lásd: 2013. évi XXVII. törvény 45.§. Elemzése: Varga 2013). 
az egyházi iskolákban tanuló hátrányos helyzetű tanuló. Ebben a fejezetben megpróbálunk magyarázatot találni arra, mi állhat a felekezeti iskolák hátrányos helyzetű tanulói létszámának növekedése mögött, valamint arra, hogy a felekezeti oktatási intézmények hogyan képesek a társadalmi egyenlőtlenségek enyhítését segíteni.

Pusztai (2014) utal rá, hogy a 2009-es oktatási közvélemény-kutatás eredményeiből kiolvasható, hogy a „felekezeti iskolák kiemelkedően eredményesek a tanulóval való törődés, a személyes odafigyelés, a hátrányos helyzetű gyerekek segítése, valamint a fogyatékos tanulók együttnevelése terén” (Pusztai 2014, 2). Továbbá hazai és nemzetközi vizsgálatok is igazolták, hogy a vallásosság erősen hat a gyermeknevelésre, az iskolaválasztásra és az iskolai karrierre egyaránt (Nagy 2003; Tomka 2008; Pusztai 2009, 2011), ahogyan hatással van a fiatalok magatartására is (Pusztai 2014, 5). A rendszerváltás idején a totális állami oktatási rendszer még képtelen volt a társadalmi egyenlőtlenség és integráció biztosítását ellátni, és még a vallásosság mentén szerveződő csoportok kultúraátadását is korlátozta (Kozma 1992; Tomka 1992). A kilencvenes években már megjelentek azok a diákokat veszélyeztető magatartásformák, amelyeket az egyházi fenntartású oktatási intézmények jobban tudtak kezelni (Pusztai 2004). Az is magyarázat lehet a kérdésünkre, hogy a felekezeti iskolafenntartók a kohezív iskolai közösségek létrehozására törekednek, valamint a felekezeti iskolát választó szülők is a kiterjesztett tanárszerep gyakorlását helyezik előtérbe az iskolaválasztás során, ami magában foglalja a tanulóval való közvetlen, személyes kapcsolattartást (Bacskai 2008; Pusztai 2009, 2011). Megállapítható, hogy a demográfiai hullámvölgy ellenére a felekezeti szektor minden iskolatípusban növekedést mutatott. „A felekezeti oktatás szolid mértékű második expanzióját az általános iskolák szintjén jórészt a kistelepülési intézmények helyzetének ellehetetlenülése okozta” (Pusztai 2014, 8). Coleman (1990) szerint az oktatáspolitika célja a társadalmi egyenlőtlenségek kiegyenlítése. Miközben minden kormányzat érdeke, hogy komprehenzív iskolákat hozzanak létre, amelyek képesek a középrétegekből származók és az alacsony státusú gyermekek integrálására, addig megfigyelhető, hogy minél magasabb az alacsony státusúak aránya egy térségben, annál inkább igaz, hogy a középrétegből származó szülők mindent megtesznek annak érdekében, hogy társadalmilag homogénebb összetételű iskolát keressenek gyermekeiknek.

Ennek tudatában feltehető a kérdés, hogy a felekezeti oktatási intézmények hogyan képesek a társadalmi egyenlőtlenségek enyhítését segíteni. Az oktatáskutatók ezt azzal magyarázzák, hogy a felekezeti iskolák egy részének ez a hagyományos küldetése (Pusztai 2004, 2009), valamint azt is bizonyították, hogy „iskolafelhasználói körük elsősorban értékorientáció és vallásosság alapján szerveződik” (Pusztai 2014, 13). Ezáltal a felekezeti iskoláknak nagyobb esélyük van több társadalmi rétegből érkező diák befogadására, hiszen „a vallásosság mentén szerveződő kapcsolathálók kötései átnyúlnak a társadalmi rétegek határain” (Pusztai 2014, 13). A felekezeti iskolák alacsony státusú társadalmi csoportok felé fordulását a hátrányos helyzetű tanulók az oktatás 
minden szintjén történő felkarolása, és az iskolaátvételek fémjelzik (Csejoszki 2012; Morvai 2014; Pusztai 2014).

\section{Vizsgálati módszerek, mérőeszközök és minták}

A kutatás kérdőíves módszerrel 2014 tavaszán a Klebelsberg Intézményfenntartó Központ (KLIK) mai elnevezése Klebelsberg Központ Nyíradonyi Tankerületének 5 intézményében (Nyíradony, Álmosd, Nyírmártonfalva, Vámospércs és Újléta) készült a 7-8. osztályos tanulók körében ( $\mathrm{N}=230$ fő). A vizsgálatban 111 fő hetedik és 119 fő nyolcadik osztályos tanuló vett részt. A vizsgált intézmények tekintetében az adatok jól mutatják, hogy a hátrányos helyzetű diákok számának százalékos aránya a vizsgált időszakban (2014) jelentősen magasabb az országos átlaghoz képest.

\section{A kutatás kérdései, hipotézisei}

A kutatás során a hátrányos helyzetű tanulók IKT iránti attitűdjét vizsgáltuk idegen nyelvi órák vonatkozásában. Arra kerestük a választ, hogy az IKT-eszközök használata hogyan jelenik meg az idegen nyelvi órán, és tanulók hogyan reagálnak erre, azaz milyen mértékben tartják fontosnak az IKT-eszközöket az idegen nyelvi foglalkozások alkalmával, valamint mennyire tartják jártasnak magukat az IKT-eszközök használatában. Azt is megvizsgáltuk, hogy találunk-e összefüggéseket különböző magyarázó változók (a tanulók neme, osztálya stb.) és a tanulók IKT-eszközökkel történő idegennyelv-tanulási attitűdje között.

\section{Hipotézisek}

1. Azt várjuk, hogy a tanulók jobban igénylik az IKT-eszközökkel támogatott idegennyelv-tanítást szemben a hagyományos IKT-eszközök nélküli idegennyelv-tanítással.

2. Azt feltételezzük, hogy a magas szintű tanórai IKT-használat pozitívan befolyásolja az idegen nyelv tanulása iránti tanulói motivációt.

\section{Eredmények}

Először azt vizsgáltuk, milyen IKT-eszközöket használnak az idegen nyelvi órákon a kutatásba bevont intézményekben. A kérdőívben 11 darab (kazettás magnó, VHS, CD-lejátszó, DVD-lejátszó, MP3-lejátszó, projektor, számítógép/ notebook, hangszóró, interaktív tábla, tablet, okostelefon) IKT-eszközt soroltunk fel. A tanulók közül 71 fő jelölte be a kazettás magnót, 81 fő a CD lejátszót 
és 95 fő az interaktív táblát. Ezek a számok csupán azt mutatják, hogy a vizsgált intézményekben van olyan idegen nyelvi óra, ahol még kazettás magnóval fejlesztik a tanulók hallásutáni értését. Az is jól látszik, hogy egyre több intézményben jelenik meg az interaktív tábla ebben a térségben is (Barnucz és Labancz 2015).

A további elemzések során arra kerestük a választ, hogy a tanulók milyen mértékben tartják fontosnak az oktatástechnikai eszközöket az idegen nyelvi tanórák, foglalkozások alkalmával (3. táblázat). Az eredmények szerint a megkérdezett tanulók 53,4 százaléka (n=102) tartja elég fontosnak. Azt látjuk, hogy nincs szignifikáns különbség a tanulók neme és aközött, hogy fontosnak tartják-e az eszközöket az idegen nyelvi órákon. A fiúk esetében látunk magasabb értéket.

\begin{tabular}{|c|c|c|c|c|c|c|c|}
\hline $\begin{array}{c}\text { sor- } \\
\text { százalék } \\
\text { (n=191) }\end{array}$ & & & $\begin{array}{c}\text { Egyáltalán } \\
\text { nem } \\
\text { tartom } \\
\text { fontosnak }\end{array}$ & $\begin{array}{c}\text { Kevésbé } \\
\text { tartom } \\
\text { fontosnak }\end{array}$ & $\begin{array}{c}\text { Elég } \\
\text { fontosnak } \\
\text { tartom }\end{array}$ & $\begin{array}{c}\text { Nagyon } \\
\text { fontosnak } \\
\text { tartom }\end{array}$ & Összesen \\
\hline \multirow{2}{*}{ Neme } & \multirow{2}{*}{ Lány } & $\mathrm{n}$ & 4 & 23 & 48 & 16 & 91 \\
\cline { 3 - 8 } & \multirow{2}{*}{ Fiú } & $\mathrm{n}$ & $4,4 \%$ & $25,3 \%$ & $52,7 \%$ & $17,6 \%$ & $100,0 \%$ \\
\cline { 3 - 8 } & & $\%$ & $6,0 \%$ & $19,0 \%$ & $54,0 \%$ & $21,0 \%$ & $100,0 \%$ \\
\hline \multirow{2}{*}{$\begin{array}{c}\text { Összesen } \\
\mathbf{P = 0 , 7 0 8}\end{array}$} & & $\mathrm{n}$ & 10 & 42 & 102 & 37 & 191 \\
\cline { 3 - 8 } & & & $5,2 \%$ & $22,0 \%$ & $53,4 \%$ & $19,4 \%$ & $100,0 \%$ \\
\hline
\end{tabular}

3. táblázat: Az IKT-eszközök fontossága az idegen nyelvi órákon a tanulók válaszai alapján² (saját szerkesztés)

Ez a következő táblázatban közölt eredményekkel is magyarázható (4. táblázat), hiszen azt is megvizsgáltuk, hogy a tanulók mennyire tartják jártasnak magukat az IKT-eszközök használatában. Azt láthatjuk, hogy kétszer annyi fiú - önbevallása szerint - jártasabb az eszközök használatában, mint lány. Valamint az is jól látszik, hogy hiába jártasabbak a tanulók az egyes eszközök használatában, nem feltétlenül tartják nagyon fontosnak azok használatát az idegen nyelvi órákon. Valószínűsíthető, hogy a lányok alábecsülik, a fiúk túlbecsülik képességeiket, hiszen az informatika autodidakta módon, felhasználói szintű tudást tekintve könnyen, gyorsan, hatékonyan elsajátítható.

2 Milyen mértékben tartod fontosnak az oktatástechnikai eszközöket az idegen nyelvi tanórákon, foglalkozásokon? 


\begin{tabular}{|c|c|c|c|c|c|c|c|}
\hline $\begin{array}{c}\text { sor- } \\
\text { százalék } \\
\text { (n=191) }\end{array}$ & & & $\begin{array}{c}\text { Egyáltalán } \\
\text { nem } \\
\text { vagyok } \\
\text { jártas }\end{array}$ & $\begin{array}{c}\text { Kevésbé } \\
\text { vagyok } \\
\text { jártas }\end{array}$ & $\begin{array}{c}\text { Elég jártas } \\
\text { vagyok }\end{array}$ & $\begin{array}{c}\text { Nagyon } \\
\text { jártas } \\
\text { vagyok }\end{array}$ & Összesen \\
\hline \multirow{2}{*}{ Neme } & \multirow{2}{*}{ Lány } & $\mathrm{n}$ & 1 & 15 & 43 & 33 & 92 \\
\cline { 3 - 8 } & \multirow{2}{*}{ Fiú } & $\mathrm{n}$ & $1,1 \%$ & $16,3 \%$ & $46,7 \%$ & $35,9 \%$ & $100,0 \%$ \\
\cline { 3 - 8 } & & $\%$ & $1,0 \%$ & $7,1 \%$ & $25,3 \%$ & $66,7 \%$ & $100,0 \%$ \\
\hline \multirow{2}{*}{$\begin{array}{c}\text { Összesen } \\
\mathbf{P = 0 , 0 0 0}\end{array}$} & & $\mathrm{n}$ & 2 & 22 & 68 & 99 & 191 \\
\cline { 3 - 8 } & & & $1,0 \%$ & $11,5 \%$ & $35,6 \%$ & $51,8 \%$ & $100,0 \%$ \\
\hline
\end{tabular}

4. táblázat: Az IKT-eszközök használatában való jártasság a tanulók válaszai alapján ${ }^{3}$ (saját szerkesztés) skálaérték: 1 = egyáltalán nem vagyok jártas; 4 = nagyon jártas vagyok az eszközök használatában.

Vizsgáltuk, hogyan értékelik a tanulók, ha a tanár IKT-eszközt alkalmaz az idegen nyelvi órákon (5. táblázat). Az eredmény alapján a tanulók izgalmasnak tartják (45,4\%), ha a tanár ilyen eszközök használatával fejleszti nyelvi készségüket. Feltételezhető, hogy amit a tanulók fontosnak tartanak, az egyben izgalmas is a számukra, ezáltal motiváltabbak lehetnek, és nagyobb érdeklődést mutathatnak az idegen nyelvi órák felé.

\begin{tabular}{|c|c|c|c|c|c|c|c|}
\hline $\begin{array}{c}\text { sor- } \\
\text { százalék } \\
\text { (n=194) }\end{array}$ & & & $\begin{array}{c}\text { Egyálta- } \\
\text { lán nem } \\
\text { izgalmas }\end{array}$ & $\begin{array}{c}\text { Nem } \\
\text { annyira } \\
\text { izgalmas }\end{array}$ & $\begin{array}{c}\text { Elég } \\
\text { izgalmas }\end{array}$ & $\begin{array}{c}\text { Nagyon } \\
\text { izgalmas }\end{array}$ & Összesen \\
\hline \multirow{2}{*}{ Neme } & \multirow{2}{*}{ Lány } & $\mathrm{n}$ & 6 & 33 & 46 & 8 & 93 \\
\cline { 3 - 8 } & \multirow{2}{*}{ Fiú } & $\mathrm{n}$ & 13 & 30 & 42 & 16 & 101 \\
\cline { 3 - 8 } & & $\%$ & $12,9 \%$ & $29,7 \%$ & $41,6 \%$ & $15,8 \%$ & $100,0 \%$ \\
\hline \multirow{2}{*}{$\begin{array}{c}\text { Összesen } \\
\mathbf{P = 0 , 1 5 4}\end{array}$} & & $\mathrm{n}$ & 19 & 63 & 88 & 24 & 194 \\
\cline { 3 - 8 } & & & $9,8 \%$ & $32,5 \%$ & $45,4 \%$ & $12,4 \%$ & $100,0 \%$ \\
\hline
\end{tabular}

5. táblázat: Az IKT-eszközök izgalmas tanórai szerepe a tanulók válaszai alapján ${ }^{4}$ (saját szerkesztés) skálaérték: 1= egyáltalán nem izgalmas; 2= nem annyira izgalmas; 3=elég izgalmas; 4=nagyon izgalmas

3 Mennyire vagy jártas az oktatástechnikai eszközök használatában?

4 Hogyan értékeled azt, ha a tanár oktatástechnikai eszközöket alkalmaz az idegen nyelvi órákon? 
További összefüggéseket kerestünk arra vonatkozóan, hogy a tanulók milyennek tartják, ha a tanár IKT-eszközökkel oktatja az idegen nyelvet, és hogy egyébként milyennek tartják az idegen nyelvi órákat IKT-eszközök használatától függetlenül (6. táblázat). Az eredmények szerint azok a tanulók, akik elég izgalmasnak tartják (66, 3 százaléka; n=55), azok az IKT-eszközök használata nélkül is izgalmasnak tartják az idegen nyelvi órákat. Azonban vannak olyan diákok is (40,8 százaléka; n=31), akik az IKT-eszközökkel támogatott idegen nyelvi órákat izgalmasabbnak tartják, mint az azokat nélkülözőket. Ezt a csoportot tehát az eszközök alkalmazása motiválja a tanulásban.

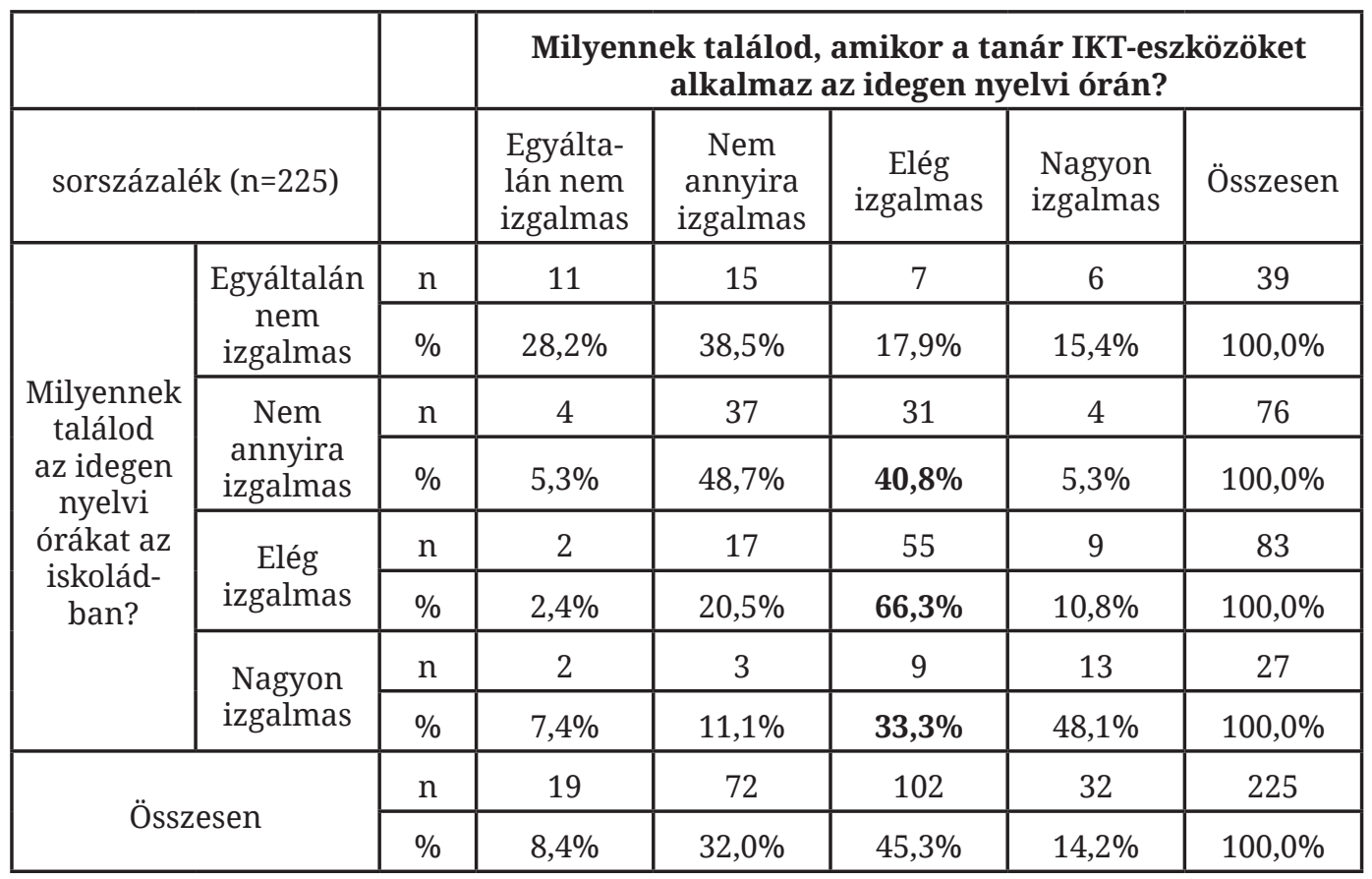

6. táblázat: Az IKT-eszközökkel támogatott vs. IKT-eszközök bevonása nélküli idegen nyelvi óra (saját szerkesztés)

Megnéztük, hogy az egyes IKT-eszközök alkalmazásához fűződő attitűdtényezők (fontosság, jártasság, izgalmas, motiváció) mennyire jellemzőek külön-külön a lányokra és fiúkra (7. táblázat). Mindössze egy attitűdtényező (jártasság) terén találtunk szignifikáns különbséget. A fiúk és a lányok is 3 feletti átlagértéket képviselnek, de a fiúk az IKT-eszközök terén bevallott jártasságának 3,58-as átlagértéke továbberősíti a fiúk esetében tapasztalt magabiztosságot. 


\begin{tabular}{|c|c|c|c|c|c|}
\hline \multirow{2}{*}{ Neme } & & Fontosság & Jártasság*** & Izgalom & Motiváció \\
\hline \multirow{2}{*}{ Fiún } & átlag & 2,84 & $\mathbf{3 , 1 7}$ & 2,6 & 2,61 \\
\cline { 2 - 6 } & $\mathrm{n}$ & 91 & 92 & 93 & 93 \\
\cline { 2 - 6 } & átlag & 2,9 & $\mathbf{3 , 5 8}$ & 2,6 & 2,52 \\
\hline Össz. & $\mathrm{n}$ & 100 & 99 & 101 & 101 \\
\hline & átlag & 2,87 & 3,38 & 2,6 & 2,57 \\
\hline & $\mathrm{n}$ & 191 & 191 & 194 & 194 \\
\hline
\end{tabular}

7. táblázat: IKT-eszközök alkalmazásával kapcsolatos attitűdtényezők nemek szerint $^{5}$ (saját szerkesztés)

Megjegyzés: $* * * \mathrm{P} \leq 0.001$

Az egyes attitűdtényezőkből kétértékű (dummy) változókat kódoltunk és varianciaanalízis statisztikai eljárást alkalmaztunk arra vonatkozóan, hogy kimutatható-e szignifikáns összefüggés az egyes IKT-attitűdtényezők és a tanulók IKT-eszköz használatában tapasztalt jártasságuk között (8. táblázat). Az eredmények szerint szignifikáns összefüggés van az IKT-eszközök oktatásban történő használatának fontossága, a tanulók tanórai motivációját vizsgáló változók és a tanulók IKT-eszköz használatában való jártassága között. Azok akik, fontosnak tartják, vagy nagyon motiváló számukra az IKT-eszközök használata az idegen nyelvi órákon, azok valószínüleg jártasabbak is az eszközök használatában.

\begin{tabular}{|c|c|c|c|}
\hline Fontosság $^{6}$ & átlag & N & szórás \\
\hline Kevésbé fontos & 3,18 & 67 & 0,737 \\
\hline Fontos & 3,49 & 156 & 0,677 \\
\hline Összesen & 3,39 & 223 & 0,708 \\
\hline Motiváció $^{7}$ & átlag & $\mathbf{N}$ & szórás \\
\hline Kevésbé motiváló $^{\text {Nagyon motiváló }}$ & 3,27 & 103 & 0,769 \\
\hline Összesen & 3,48 & 121 & 0,660 \\
\hline
\end{tabular}

8. táblázat: IKT-eszközök alkalmazásával kapcsolatos attitűdtényezők (saját szerkesztés)

5 ANOVA teszt az IKT-eszközökben való jártasság kapcsán: 0,000

6 ANOVA teszt az IKT-eszközök fontossága és a jártasság kapcsán: 0,003

7 ANOVA teszt az IKT-eszközök fontossága és a motiváció kapcsán: 0,031 
Azt is feltártuk, hogy a megkérdezett tanulók leginkább hogyan szeretnek - vagy hogyan szeretnének - idegen nyelvet tanulni. A felsorolt válaszlehetőségek közül ${ }^{8}$ több lehetőséget is megjelölhettek (9. táblázat). Ezzel a kérdéssel azt is megvizsgáltuk, milyen gyakorisággal jelölik a tanulók az IKT-eszközökkel támogatott opciót. Ami az elemszámot illeti, a hatalmas válaszhiány ellenére is a digitális eszközök segítségével történő idegennyelv-tanulás tűnt a leginkább motiválónak a számukra ( $n=42)$ (Borszéki 2014b, 2019; Labancz és Barnucz 2016).

Ezáltal beigazolódni látszik, hogy a mai nyelvtanulók a 21. század lehetőségeit kihasználva, az IKT-eszközöknek köszönhetően kreatívan alkalmazhatják a hatékony nyelvelsajátításhoz vezető lépéseket (hallgathatják, utánozhatják, ismételhetik, gyakorolhatják az egyes kifejezéseket) (Matthey 2006; Polonyi, Abari és Nótin 2009). Barnucz (2019b) egy longitudinális vizsgálat keretében tanulmányozta az IKT-eszközök szerepét az angol nyelvoktatásban. Kutatási eredményei azt hangsúlyozzák, hogy a kísérleti és a kontrollcsoport eredményeiben ugyan nem volt tapasztalható szignifikáns különbség az elő és az utómérés között, azonban a vizsgálati csoport utómérésének eredményei az előmérés eredményeihez képest pozitív irányú elmozdulás mutatkozott, ugyanis az egyes nyelvi készégek mentén ebben magasabb képességpont-átlagok voltak megfigyelhetők. Czékmán (2018) kutatási eredményei hasonlóak. Kutatásában tablettel támogatott nyelvtanulást vizsgált a Kispesti Puskás Ferenc Általános Iskola alsó tagozatos (4. osztály) tanulói körében ( $\mathrm{N}=38$ ). A hatékonyságvizsgálat eredményei alapján a mobiltechnológiával támogatott szótanulás elsősorban a jobb teljesítményszintű diákok esetében volt hatékony. A kísérleti csoport tagjai (n=20) szerint a tablettel támogatott szótanulás szórakoztató és gyors (60\%, 12 válasz), továbbá kiemelték a kiejtés gyakorlásának lehetőségét, a rendelkezésre álló feladatok széles skáláját stb. A válaszokból kiderül továbbá, hogy a tanulók pozitívan viszonyulnak a tablettel való szótanuláshoz. Az eredmények azt mutatják, hogy a diákok szívesebben tanulják az angol szavakat a tabletek segítségével, mint füzetből. Ezzel jól bizonyítható az Európai Unió által meghatározott két kulcskompetencia (idegen nyelvi kommunikáció és digitális

8 Véleményed szerint, hogyan lehet a leghasznosabban elsajátítani egy idegen nyelvet az iskolában?

A) ha vicces idegen nyelvü oldalakat olvasunk az interneten;

B) ha a kifejezéseket állandóan csak magoljuk;

c) mindegy hogyan tanuljuk, mert az idegen nyelveket rosszul is érdemes tudni;

D) az motivál, hogy kevés tudással is messzire érhetek;

E) párbeszédek memorizálásával;

F) digitális, játékos tananyagok használatával;

G) digitális eszközök segítségével a tanár által készített feladatokkal;

н) Egyéb. 
kompetencia) iskolai oktatásban előforduló találkozási pontja, hiszen egyik sem tud létezni a másik nélkül. Ma a 21. században az idegen nyelvi képességek fejlesztése sokkal hatékonyabb lehet a digitális lehetőségek, megoldások megfelelő szintű és minőségű használatával.

\begin{tabular}{|c|c|c|c|c|c|c|}
\hline \multicolumn{2}{|c|}{} & \multicolumn{5}{|c|}{ Motiváló-es számodra, ha a tanár használ IKT eszközt idegen } \\
nyelvi órán?
\end{tabular}

9. táblázat: IKT-eszközök alkalmazásával kapcsolatos attitüdtényezők ${ }^{9}$ (saját szerkesztés)

A táblázat eredményei azt mutatják, hogy azon tanulók számára motiváló leginkább az, ha a tanár használ valamilyen IKT-eszközt az idegen nyelvi órák keretében, akik jó vagy nagyon jó tanulónak tartják magukat. Ezt Czékmán (2018) kutatási eredményei is megerősítik, hiszen azt állapította meg, hogy a mobiltechnológiával támogatott oktatási környezet leginkább a jobb képességszintű tanulókat motiválta. Továbbá a szókincs-elsajátításra vonatkozó eredmények is azt mutatták, hogy a jobb teljesítményszintű csoportok számára hatékonyabb volt a mobiltechnológiával támogatott oktatási környezet, mint a gyengébb teljesítményszinttel rendelkező tanulók számára. Ennek valószínűleg az lehet az oka, amit Max Weber (1982) és Bourdieu (1978) is tárgyalnak a társadalmi státus és a kulturálisan kódolt érték-döntések hatása kapcsán, mely a nyelvtanulásra is érvényes (Novák és Morvai 2017). Ezt a jelenséget az magyarázhatja, hogy a feltörekvő középréteg, vagy a magasabb iskolai végzettséggel rendelkező szülők anyagi erőforrásuk nagy részét gyermekeik iskolán kívüli támogatására fordítják. Ebből adódik, hogy ezeknek a

9 Hogyan értékeled magadra nézve, ha a tanár oktatástechnikai eszközt alkalmaz az idegen nyelvi órákon? 
gyerekeknek már az otthoni környezetben is elérhetők a különböző technológiai eszközök, melynek hála rugalmasabban is kezelik és tartják fontosnak ezeket.

\section{Összegzés}

Az eredményeink alapján nem vonhatunk le messzemenő következtetéseket a tanulók IKT-eszközökkel történő idegennyelv-tanulási attitűdjére vonatkozóan. Azt feltételeztük, hogy a tanulók jobban igénylik az IKT-eszközökkel támogatott idegennyelv-tanulást, szemben a hagyományos, IKT-eszközök nélküli idegennyelv-tanulással. Az eredmények az IKT-eszközök használatának fontosságát, a tanulók eszközökben való jártasságát és azok pozitív hatását, valamint motiváló erejét hangsúlyozták. A fiúk esetében kiemelkedő magabiztosságot tapasztaltunk az eszközök használatában, amely végig tapasztalható volt a vizsgálat során.Ezt az informatikai érdemjegyek feltárásával lehetne jobban alátámasztani. Elképzelhető, hogy a fiúk túlbecsülik, a lányok alábecsülik informatikai tudásukat. Megfigyelhető volt, hogy azok a tanulók, akik számára fontos vagy motiváló az IKT-eszközök használata az idegen nyelvi órákon, valószínűleg jártasabbak is az eszközök használatában. A második hipotézisünk az volt, hogy a magas szintű tanórai IKT-használat pozitívan befolyásolja az idegen nyelv tanulása iránti tanulói motivációt. Ez a feltevésünk is beigazolódni látszott, hiszen szignifikáns összefüggés van az IKT-eszközök oktatásban történő használatának fontosságát, a tanulók IKT-eszközök iránti motivációját vizsgáló változók és a tanulók IKT-eszközök használatában való jártassága között. A jövőben érdemes lenne vizsgálni, hogy a hatékony idegennyelv-tanulás együtt jár-e az IKT-eszközök hatékony alkalmazásával. Ezt valószínüleg egy longitudinális vizsgálat során lehetne bizonyítani, ahol kísérleti (IKT-csoport) és kontrollcsoportok (nem IKT-csoport) eredményességére koncentrálnánk.

\section{Irodalom}

Bacskai Katinka, „Református iskolák tanárai”, Magyar Pedagógia, 108. évf. (2008) 4. szám, 359-378. old. http://bit.ly/20mCJYp

Balogh András, „Centrum-periféria relációk és marginalizáció”, in Szónokiné Ancsin G. (szerk.), Határok és az Európai Unió, Szeged: SZTE TTK Gazdaság- és Társadalomföldrajz Tanszék, 2002, 208-214. old.

Bárdos Jenő (szerk.), Az idegen nyelvek tanításának elméleti alapja és gyakorlata, Budapest:

Nemzeti Tankönyvkiadó, 2000. http://bit.ly/331GcRk 
Barnucz Nóra és Labancz Imre, „Pedagógusok és az IKT Magyarország keleti régióiban”, in Puszta Gabriella és Morvai Laura (szerk.), Igények és lehetőségek a pedagógus-továbbképzés változó rendszerében, Nagyvárad-Budapest: Partium Könyvkiadó, 2015, 235-245. old. http://bit.ly/2r32vZK

Barnucz Nóra, „Digitális egyenlőtlenségek a szociológiai elemzések tükrében”, in Karlovitz János Tibor, (szerk). Tanulmányok a kompetenciákra építő, fenntartható kulturális és technológiai fejlődés köréből, Komárno, International Research Institute s.r.o. 2019a, 205-212. old.

Barnucz Nóra, „IKT eszközök szerepe az angol nyelv oktatásában”, Educatio, 28. évf. (2019b) 2. szám. 403-414 old. http://bit.ly/36WQYuI https://doi.org/10.1556/2063.28.2019.2.14

Barnucz Nóra, „IKT-eszközökkel Támogatott (Rendészeti) Nyelvoktatás”, Magyar Rendészet, (2019c) (megjelenés alatt)

Bernstein, Basil, „Nyelvi szocializáció és oktathatóság”, in Pap Mária és Szépe György (szerk.), Társadalom és nyelv, (Szociolingvisztikai írások), Budapest: Gondolat Kiadó , 1975, 393-435. old. http://bit.ly/35ovOoz

Bernstein, Basil, „Iskolai tudásanyag osztályozásáról és kereteiről (framing)”, in Az iskola szociológiai problémái, Budapest: KJK, 1974, 123-153. old. http://bit.ly/2r5P0bs

Borszéki Judit, „A webinárium helye az elektronikus tanulási környezetben, alkalmazásának lehetőségei a rendészeti képzésben” Magyar Rendészet, 13. évf. (2013) 1. szám, 105-117.

old. http://bit.ly/35doEDh

Borszéki, Judit, „The principles of modern language teaching represented in an EU training tool for border guards II.” Hadtudományi Szemle, VII. évf. (2014a) 2. szám, 106-122. old. http://bit.ly/35fk1sy

Borszéki, Judit, „Activities that have worked well in teaching ESP”, in Fregan Beatrix (eds), Success and Challenges in Foreign Language Teaching: International Conference for Language Instructors, Budapest: Nemzeti Közszolgálati Egyetem, 2014b, pp. 55-64. https://doi. org/10.17625/NKE.2016.17 http://bit.ly/20nqCdr

Borszéki Judit, „E-learning anyagok használata az angol rendészeti szakmai nyelv oktatásában” Rendőrségi tanulmányok, 2. évf. (2019) 3. szám, 115-149. old. http://bit.ly/35doEDh

Bourdieu, Pierre, A társadalmi egyenlőtlenségek újratermelődése, Budapest Gondolat: Kiadó, 1978.

Buda András, IKT és oktatás - Együtt vagy egymás mellett?, Belvedere Meridionale kiadó, Debreceni Egyetem BTK Humán Tudományok Doktori Iskola, HERA IKT szakosztály, 2017. http://bit.ly/2CRGEqG

Butler, Yuko, Goto, „Parental factors and early English education as a foreign language: A case study in Mainland China”, Research Paper in Education. Vol. 29. (2013) No. 4. pp. 410-437. https://doi.org/10.1080/02671522.2013.776625. http://bit.ly/2XrO9hJ

Coleman, James, Samuel, Equality and achievement in education, New York: Westview, 1990.

Czékmán Balázs, „Tabletek és módszerek: A mobiltechnológia tanórai alkalmazása a pedagógia szemszögéből”, in Buda András és Kiss Endre, (szerk.), Interdiszciplináris pedagógia és a taneszközök változó regiszterei, Magyarország, Debrecen: Debreceni Egyetem Neveléstudományok Intézete, Kiss Árpád Archívum Könyvtára, 2018, 95-105. old.

Crystal, David, English as a Global Language, Cambridge: Cambridge University Press, 1998. http://bit.ly/37jl1gU 
Csejoszki Mihály, „Egyházi szerepvállalás - Iskolaátadások a Csereháton”, in: Buda András és Kiss Endre (szerk.), Interdiszciplináris pedagógia és a felsőoktatás alakváltozásai, Debrecen: Debreceni Egyetem Neveléstudományok Intézete, 2012. 130-137. old.

Csizér, Kata és Dörnyei, Zoltán, „Language Learners’ Motivational Profiles and Their Motivated Learning Behavior”, Language Learning, Vol. 55. (2005) No. 4., pp. 613-659. http://bit. ly/35ibHs3

Denis, Lawton, Társadalmi Osztály, Nyelv és Oktatás, Budapest: Gondolat, 1974.

Einhorn Ágnes (szerk.), A pedagógiai modernizáció és az idegennyelv-tanítás, Pedagógiai kultúra 3., Miskolc: Miskolci Egyetemi Kiadó, 2015. http://bit.ly/35bECOK

Edwards, J. R., „Characteristics of disadvantaged children”, The Irish Journal of Education, Vol. 8. (1974) No. 1., pp. 49-61. http://bit.ly/2CXmZWh

Erdész Tiborné és Timár János, „Családi-társadalmi környezet, pályaválasztás, továbbtanulás”, Valóság 8. évf. (1967) 5-20. old.

Fehér, Péter, Czékmán Balázs and Aknai, Dóra, Orsolya, „Complex competency development with augmented reality supported digital storytelling”, HERJ - Hungarian Educational Research Journal, Vol. 8. (2018) No. 1., pp. 93-96. http://bit.ly/35friZ8

Fejes József Balázs, „Miért (nem) fontosak a hátrányos helyzetű tanulók?”, Új Pedagógiai Szemle, 56. évf. (2006) 7-8. szám. 17-26. old. http://bit.ly/2CWC0I4

Fejes József Balázs és Józsa Krisztián, „Az iskolai eredményesség és a tanulási motiváció kulturális jellemzői”, Iskolakultúra, 17. évf. (2007) 6-7. szám, 83-96. old. http://bit. ly/2XwnqQX

Ferge Zsuzsa, „A társadalmi struktúra és az iskolarendszer közötti néhány összefüggés”, Szociológia, 1. szám, (1972). 10-35. old.

Folse, Keith, S., "Myths about Teaching and Learning Second Language Vocabulary: What Recent Research says”, TESL Reporter. Vol. 37. (2004) No. 2. pp. 1-13. http://bit.ly/33UIKlz

Fónai Mihály, Balogh Erzsébet, Barnucz Nóra, Hüse Lajos és Zolnai Erika, „The Roma Population of Small Towns”, in Hanna, Liberska, Marzana, Farnick (eds.), „A Child of Many Wolrds: Focus on the Problems of Ethinc Minorities”, Németorzág, Frankfurt: Peter Lang Verlag, 2014, pp. 85-109.

Gazsó Ferenc (szerk.), Iskolarendszer és társadalmi mobilitás, Budapest: Kossuth, 1976.

Gidáné Orsós Erzsébet, „A hátrányos helyzetről”, Tudás Menedzsment, 2. szám, (2006), 75-81. old. http://bit.ly/20odaWP

Heckman, James, J. and Masterov, Dimitriy, V., „The productivity argument for investing in young children”, Review of Agricultural Economics, Issue 3., (2007), pp. 449-493. http://bit. ly/3418WuN

Kétyi András (szerk.), IKT-val támogatott módszerek hatékonysága felnőttek nyelvoktatásában. PhD értekezés. Szegedi Tudományegyetem, Bölcsészettudományi Kar Neveléstudományi Doktori Iskola, 2016.

Kormos Judit és Csizér Kata, „A családi környezet hatása az idegen nyelvi motivációra: egy kvalitatív módszerekkel történő kutatás tanulságai”, Magyar Pedagógia, 105. évf. (2005) 1. szám, 29-40. old. http://bit.ly/37iijbx

Kozma Tamás (szerk.), Hátrányos helyzet, Budapest: Tankönyvkiadó, 1975. http://bit. ly/2XplKIQ

Kozma Tamás, „Egyház és demokrácia”, Educatio, 1. szám, (1992), 1-3. old. http://bit.ly/33UJZBf 
Labancz Imre és Barnucz Nóra, „Kísérlet az IKT-eszközhasználat hatásának vizsgálatára hallgatók körében”, in Pusztai Gabriella, Bocsi Veronika és Ceglédi Tímea (szerk.), A felsőoktatás (hozzáadott) értéke. Közelitések az intézményi hozzájárulás empirikus megragadásához, Budapest, Magyarország, Nagyvárad, Románia: Partium, Új Mandátum, 2016. http://bit.ly/2Qv3a0H

Liskó Ilona, „A hátrányos helyzetű tanulók oktatásának minősége”, Új Pedagógiai Szemle, 2. szám, (2002), 56-69. old. http://bit.ly/2pvaxdr

Matthey, Marienette, Bange Pierre (en collaboration avec Rita Carol et Peter Griggs). Lidil 34. 2006. http://bit.ly/2ndjreg

McClelland, David, C., Baldwin, Alfred, L., Bronfenbrenner, Urie and Strodbeck, Fred, L (eds.), Talent and Society: New Perspectives in the identification of talent. New York: Van Nostrand, 1958.

Meleg Csilla (szerk.), Iskola és Társadalom I. Szöveggyűjtemény, Pécs: JPTE Tanárképző Intézet Pedagógia Tanszéke, 1996. http://bit.ly/2r5P0bs

Molnár Katalin és Uricska Erna, „The Police Cafe: An efficient method for improving the dialogues between the Police and the community”, European Law Enforcement Reserach Bulletin - Special Conference Editions (2018) 338/294, no. 4. p. 8.

Molnár Miklós (szerk.), Civil társadalom és akiknek nem kell, Budapest: Educatio kiadó, 1996. Morvai Laura, „Pedagógusok a fenntartóváltás után”, in Pusztai Gabriella és Lukács Ágnes (szerk.), Közösségteremtők, Debrecen: Debreceni Egyetem Kiadó, 2014, 172-194. old. http://bit.ly/37ijpnF

Nagy Attila (szerk.), Háttal a jövőnek, Budapest: Gondolat, 2003. http://bit.ly/2r3UMKZ

Novák Ildikó és Morvai Laura, „Fiatalok Nyelvtanulásának életkori és társadalmi összefüggé-

sei”, Pedacta, 7. évf. (2017) 1. szám, 47-58. old. http://bit.ly/37gMikb

Polonyi Tünde, Abari Kálmán és Nótin Ágnes, „Mesterséges nyelvtanulás első benyomás

alapján”, Alkalmazott Pszichológia, 11. évf. (2009) 1-2. szám, 5-26. old. http://bit.ly/2QCeOGS

Pusztai Gabriella (szerk.), Iskola és közösség. Felekezeti középiskolások az ezredfordulón, Budapest: Gondolat, 2004. http://bit.ly/35hTefg

Pusztai Gabriella (szerk.), A társadalmi tőke és az iskola. Új Mandátum, Budapest. 2009. http:/l bit.ly/2KwAMr4

Pusztai Gabriella, „Vallásosság és pedagógiai ideológiák”, Educatio, 1. szám (2011), 48-61. old. http://bit.ly/2pyWELk

Pusztai Gabriella, „A felekezeti oktatás új szerepekben”, Educatio, 23. évf. (2014) 1. szám, 5066. old. http://bit.ly/2KybRU8

Selinker, Larry, “Interlanguage”, International Review of Applied Linguistics in Language Teaching, Vol. 10, (1972) No. 3. pp. 209-231.

Szántó Szilvia, „A középpontban: a hallgatók, mint vevők”, Kanyar, a BGF Külkereskedelmi Kar Független Hallgatói Lapja, 7. évf. (2004) 2. szám. 4-6. old.

Tomasello, Michael (eds.), Constructing a Language: A Usage-Based Theory of Language Acquisition. Cambridge, MA: Harvard University Press, 2003.

Tomka Miklós, „Vallás és Iskola”, Educatio, 1. évf. (1992) 1. szám 13-25. old.

Tomka Miklós, „A vallástudomány mibenléte - a társadalomtudományok szemszögéből és a jelenlegi tudományos gyakorlat fényében”, Vallástudományi Szemle, 4. szám (2008), 75-86. old. 
Ürmösné Simon Gabriella, „A Case Study Based on a Spontaneous Discourse of Greek-Hungarian Bilinguals in Respect of Interjections, Swear Words and Syntactical Mistakes, as Regards Gender”, Magyar Rendészet, Vol. 17. (2017) No. 4., pp. 193-210. Nordex Nonprofit Kft. - Dialóg Campus, Budapest: Nemzeti Közszolgálati Egyetem Rendészettudományi Kar http://bit.ly/2OnzzUe

Varga Aranka: Hátrányos helyzet az új jogszabályi környezetben. Iskolakultúra, 3-4. szám (2013). 134-137. old

Varga Aranka, „Hátrányos helyzet az iskolarendszerben”, in Cserti Csapó Tibor (szerk.), Legyen az esély egyenlő: Esélyteremtés a Sásdi kistérségben, Pécs, Sásd: PTE BTK NTI Romológia és Nevelésszociológiai Tanszék; Sásdi Többcélú Kistérségi Társulás, 2014, 155-171. old. $\underline{\text { http://bit.ly/35dvRmP }}$

Vecsernyés Ildikó és Irene Wichmann, „A szókincs tanításának néhány kérdése az egyetemen kívüli felnőttoktatásban és a Hungarobox project”, THL2, 1-2.szám (2013), 119-123.old. http://bit.ly/33ZEDVh

Weber, Max (eds.), A protestáns etika és a kapitalizmus szelleme, Budapest: Gondolat Kiadó, 1982.

Jelentések

Bericht über die Durchführung des Aktionsplans „Förderung des Sprachenlernens und der Sprachenvielfalt, Kommission der Europäischen Gemeinschaften, Brüssel, 2007.

http://ec.europa.eu/education/languages/archive/doc/com554 de.pdf

European Commission, Europeans and their Languages. Report, Special Eurobarometer 386., 2012. http://ec.europa.eu/public opinion/archives/ebs/ebs 386 en.pdf

National Reading Panel, Teaching Children to Read: and evidence-based assessment of the scientific research literature on reading and its implications for reading instruction. Reports of subgroups. NICHD. 2000. 